\title{
Efek Penggunaan Cairan lonik sebagai Aditif terhadap Konduktivitas Ionik Elektrolit Baterai Ion Litium
}

\author{
Atut Reni Septiana ${ }^{1 *}$, Evvy Kartini², Wagiyo Honggowiranto², Sudaryanto², dan \\ Rahmat Hidayat ${ }^{3}$ \\ ${ }^{1}$ Program Studi Fisika, Jurusan Sains Teknologi Pangan dan Kemaritiman, Institut Teknologi Kalimantan, Jl. \\ Soekarno Hatta KM 15, Balikpapan Utara 76127, Kalimantan Timur \\ ${ }^{2}$ Pusat Sains dan Teknologi Bahan Maju, Badan Tenaga Nuklir Nasional, Kawasan Puspiptek, Serpong \\ 15314, Tangerang, Banten \\ ${ }^{3}$ Jurusan Fisika, Fakultas Matematika dan Ilmu Pengetahuan Alam, Institut Teknologi Bandung, Jl. Ganesha \\ No.10, Bandung 40132, Jawa Barat \\ *atutrenis@gmail.com
}

\section{ABSTRACT}

Lithium ion battery technology is an alternative energy supply for portable equipment, electronics devices and high power applications such as electric vehicle and power storage for renewable energy. Electrolyte of lithium ion battery plays an important role in determining battery performance. It consists of lithium salt, commonly use lithium hexafluorophosphate $\left(\mathrm{LiPF}_{6}\right)$, dissolved in organic carbonate solvent and additives. However, $\mathrm{LiPF}_{6}$ is thermally unstable and influence battery performance significantly. Moreover, the standard solvent also has some disadvantages on the electrical vehicle application. Because of this drawback, the selection of another lithium salt, lithium bis (trifluoromethylsulfonyl) imide (LiTFSI) combined with ionic liquid BMIMTFSI become a great importance. Therefore, in this study, ionic conductivity characteristics of liquid electrolyte based on LiTFSI was investigated. The ionic conductivity measurement of lithium bis (trifluoromethylsulfonyl) imide (LiTFSI) electrolyte in carbonate solvents with and without ionic liquid BMIMTFSI as an additive have been investigated. The ionic conductivity of LiTFSI with ionic liquid is larger than LiTFSI without ionic liquid as an additive, namely $3.1 \mathrm{mS} / \mathrm{cm}$ and $2.7 \mathrm{mS} / \mathrm{cm}$.

Keywords: lithium ion battery, electrolyte, LiPF6, LiTFSI, ionic liquid BMIMTFSI.

\section{ABSTRAK}

Teknologi baterai litium ion merupakan alternatif penyuplai energi pada peralatan portabel, divais elektronik, dan aplikasi tenaga tinggi seperti kendaraan listrik dan penyimpanan daya untuk energi terbarukan. Pada baterai litium ion, elektrolit memainkan peranan penting pada performa baterai. Elektrolit baterai litium ion, pada umumnya terdiri dari garam litium yang dilarutkan dalam pelarut organik dan aditif. Namun, $\mathrm{LiPF}_{6}$ tidak stabil secara termal dan mempengaruhi performa baterai secara signifikan. Selain itu, pelarut standar (konvensional) juga memiliki beberapa kekurangan jika diaplikasikan pada kendaraan listrik. Terkait dengan masalah tersebut, penggunaan elektrolit jenis lainnya, yakni garam litium, seperti lithium bis (trifluoromethylsulfonyl) imide (LiTFSI) yang dapat dikombinasikan dengan cairan ionik menjadi sangat penting untuk dikaji. Oleh karena itu, dalam penelitian ini telah dikaji karakteristik konduktivitas ionik elektrolit berbasis LiTFSI. Pengukuran konduktivitas ionik elektrolit (LiTFSI) dalam pelarut karbonat dengan dan tanpa cairan ionik BMIMTFSI sebagai aditif telah dilakukan. Konduktivitas ionik elektrolit LiTFSI dalam pelarut karbonat dengan tambahan cairan ionik lebih tinggi dibandingkan LiTFSI tanpa tambahan cairan ionik, masing-masing yaitu $3,1 \mathrm{mS} / \mathrm{cm}$ and $2,7 \mathrm{mS} / \mathrm{cm}$.

Kata kunci: baterai ion litium, elektrolit, $\mathrm{LiPF}_{6}$, LiTFSI, cairan ionik BMIMTFSI. 


\section{PENDAHULUAN}

Energi merupakan sumber kehidupan masyarakat modern. Penggunaan transportasi listrik dan teknologi informasi (TI) yang mengalami kemajuan secara signifikan seiring dengan perkembangan produk elektronik portabel seperti kamera video, ponsel, dan komputer mengharuskan kita menggunakan energi terbarukan. Ada kebutuhan mendesak untuk merancang sistem penyimpanan energi listrik guna menyeimbangkan permintaan sumber energi terbarukan dan untuk mendukung kehadiran kendaraan listrik. Revolusi tersebut menyebabkan kebutuhan baterai isi ulang dengan kapasitas yang lebih besar atau dengan ukuran dan berat yang semakin kecil untuk kapasitas tertentu semakin meningkat.

Baterai ion litium merupakan salah satu bentuk penyimpan energi listrik yang banyak digunakan untuk perangkat portabel divais elektronik. Pada baterai ion litium, elektrolit memainkan peranan penting pada performa baterai. Elektrolit baterai ion litium terdiri dari garam litium yang dilarutkan dalam pelarut organik dan aditif ${ }^{[1]}$. Baterai ion litium komersil pada umumnya menggunakan lithium hexafluorophosphate $\left(\mathrm{LiPF}_{6}\right)$ dalam pelarut organik sebagai elektrolit karena memiliki konduktivitas ionik yang tinggi, misalnya $1 \mathrm{M}$ $\mathrm{LiPF}_{6}$ dalam EC:DEC (1:1) dan $1 \mathrm{M} \mathrm{LiPF}_{6}$ dalam EC:DMC (1:1) masing masing memiliki konduktivitas sekitar $7 \mathrm{mS} / \mathrm{cm}$ dan $10 \mathrm{mS} / \mathrm{cm}^{[2,3]}$. Namun ketika menggunakan $\mathrm{LiPF}_{6}$ ada masalah terkait reaktivitasnya dengan uap air yang terperangkap dalam pelarut dan sulit untuk dikontrol. $\mathrm{LiPF}_{6}$ secara alami terdekomposisi membentuk LiF, yang merupakan asam lewis kuat, dan $\mathrm{PF}_{5}$ yang bereaksi dengan uap air seperti ditunjukkan pada persamaan reaksi berikut:

$$
\begin{gathered}
\mathrm{LiPF}_{6} \rightarrow \mathrm{LiF}+\mathrm{PF}_{5} \\
\mathrm{PF}_{5}+\mathrm{H}_{2} \mathrm{O} \rightarrow \mathrm{POF}_{3}+2 \mathrm{HF}
\end{gathered}
$$

Selanjutnya $\mathrm{POF}_{3}$ kemungkinan bisa mengalami reaksi lagi dengan uap air seperti reaksi persamaan berikut:

$$
\mathrm{POF}_{3}+\mathrm{H}_{2} \mathrm{O} \rightarrow \mathrm{POF}_{2}(\mathrm{OH})+\mathrm{HF}
$$

Dalam reaksi tersebut ada gas yang dilepaskan sehingga $\mathrm{LiPF}_{6}$ menjadi tidak stabil dan kemungkinan bisa menyebabkan ledakan sel yang konsekuensinya terjadi pelepasan produk dekomposisi yang beracun. Selain itu, produk hasil reaksi antara $\mathrm{PF}_{5}$ dengan uap air tersebut sangat reaktif terhadap kedua elektroda negatif dan positif sehingga dapat mempengaruhi performa baterai secara signifikan ${ }^{[4,5,6]}$. Terkait dengan masalah tersebut, penggunaan garam litium lain yang dilarutkan dalam pelarut organik karbonat untuk menggantikan $\mathrm{LiPF}_{6}$ menjadi sangat penting ${ }^{[7,8,9,10]}$. Lithium bis(trifluoromethylsulfonyl) imide (LiTFSI) merupakan kandidat yang paling menjanjikan sebagai pengganti LiPF$_{6}$. LiTFSI dapat digunakan sebagai elektrolit pada baterai ion litium karena konduktivitasnya yang tinggi, tidak sensitif terhadap moisture, memiliki stabilitas termal dan stabilitas elektrokimia yang tinggi, dibandingkan $\mathrm{LiPF}_{6}{ }^{[11,12]}$.

Pelarut organik yang sering digunakan adalah propilen karbonat (PC) karena memiliki banyak keuntungan dibanding pelarut karbonat organik lainnya untuk penggunaan elektrolit baterai ion litium, misalnya harganya murah dan memiliki performa yang baik pada suhu rendah. Namun penggunaan PC pada baterai ion litium memiliki masalah karena kointerkalasi molekul pelarut bersama ion $\mathrm{Li}^{+}$pada grafit dan menyebabkan pengelupasan [13]. Pelarut berbasis PC tidak melibatkan pengelupasan yang sempurna pada grafit melainkan peretakan pada struktur grafit yang dapat dilihat secara makroskopik. Hal ini terjadi karena tekanan gas hasil reduksi PC, yaitu gas propilen yang terus menerus 
dihasilkan pada elektroda grafit ${ }^{[14]}$. Pelarut organik seperti etilen karbonat (EC) dapat membentuk lapisan solid electrolyte interface yang lebih stabil daripada pelarut organik lainnya termasuk PC ${ }^{[13]}$. Oleh karena itu, untuk mencegah kointerkalasi PC dan pengelupasan grafit maka pelarut EC yang bisa membentuk lapisan SEI stabil dapat dikombinasikan dengan PC atau digunakan sebagai pengganti PC. Selain itu, pelarut EC memiliki konstanta dielektrik yang tinggi sehingga memiliki kemampuan yang baik dalam melarutkan garam litium. Namun, EC memiliki titik leleh yang tinggi $\left(\sim 36^{\circ} \mathrm{C}\right)$ sehingga perlu ditambahkan pelarut seperti diethyl carbonate (DEC) yang dapat menurunkan titik leleh tersebut ${ }^{[15] \text {. }}$

Jenis elektrolit cair selain menggunakan pelarut organik karbonat adalah menggunakan cairan ionik karena secara umum penggunaan pelarut karbonat organik seperti EC, DEC, dan PC memiliki tingkat volatilitas dan flammabilitas yang tinggi sehingga mengurangi tingkat keamanan baterai. Cairan ionik merupakan alternatif elektrolit yang sangat menarik untuk membuat baterai ion litium menjadi lebih aman. Cairan ionik memiliki stabilitas elektrokimia yang lebar, stabilitas termal tinggi, bersifat non volatil dan non flammabilitas [16]. Cairan ionik memiliki karakteristik yang unik karena memiliki struktur ion yang khas. Cairan ionik secara termal lebih stabil dari pelarut karbonat konvensional karena terbentuk dari ikatan ionik yang kuat daripada ikatan molekul pelarut karbonat organik. Hal ini yang menyebabkan cairan ionik tidak mudah terbakar dan tingkat volatilitas dapat diabaikan. Cairan ionik dengan tingkat viskositas sedang memiliki konduktivitas ion tinggi karena terdiri dari spesies ion (Tabel 1). Selain itu cairan ionik stabil secara kimia dan elektrokimia. Cairan ionik memiliki stabilitas oksidatif yang baik, stabil di atas 4V [17]. Sebagai pelarut, cairan ionik merupakan material yang mahal dan memiliki viskositas yang tinggi, terutama ketika digunakan untuk melarutkan garam litium yang menyebabkan transfer $\mathrm{Li}^{+}$rendah dibandingkan dengan elektrolit berbasis pelarut organik karbonat. Oleh karena itu, penggunaan cairan ionik sebagai pelarut garam litium dikombinasikan dengan pelarut organik karbonat ${ }^{[18]}$.

Tabel 1. Perbandingan besar konduktivitas ion dan viskositas beberapa cairan ionik dan pelarut karbonat konvensional $[15,19,20]$

\begin{tabular}{lll}
\hline Pelarut & Konduktivitas Ionik $(\mathrm{mS} / \mathrm{cm})$ & Viskositas $(\mathrm{cP})$ \\
\hline BMIMBF$_{4}$ & 3,5 & 180 \\
BMIMTFSI $_{\text {EMIMBF }}$ & 3,9 & 52 \\
BMPyrTFSI & 14 & 25,7 \\
EC & 2,2 & 8,5 \\
PC & $1 \times 10^{-4}-3 \times 10^{-4}$ & 1,9 \\
\hline
\end{tabular}

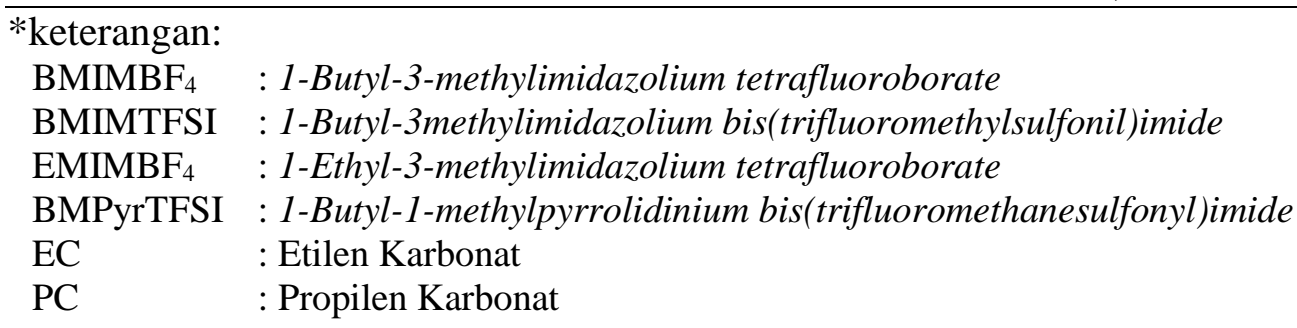

Dalam penelitian ini, telah dilakukan pengukuran konduktivitas elektrolit baterai ion litium berbasis elektrolit cair dengan garam litium LiTFSI dalam pelarut karbonat dan cairan ionik BMIMTFSI sebagai aditif. Cairan ionik BMIMTFSI yang digunakan sebagai aditif 
merupakan cairan ionik berbasis anion TFSI $^{-}$dan memiliki kelarutan yang baik untuk garam LiTFSI. Selain itu, cairan ionik tersebut memiliki stabilitas elektrokimia yang tinggi dan memiliki siklus yang baik dalam baterai ion litium karena memiliki konduktivitas ionik yang tinggi dan viskositas yang rendah. Dilihat dari konduktivitas ioniknya, elektrolit yang memenuhi kriteria sebagai elektrolit baterai ion litium yaitu memiliki konduktivitas ionik di atas $10^{-1} \mathrm{mS} / \mathrm{cm}^{[3]}$.

\section{METODE PENELITIAN}

\section{Pembuatan Elektrolit}

Elektrolit yang digunakan dalam penelitian ini adalah garam LiTFSI yang dilarutkan dalam pelarut EC:DEC (1:1). Selain itu, LiTFSI 1M dalam EC:DEC (1:1) diberikan pelarut aditif berupa cairan ionik BMIMTFSI dengan perbandingan LiTFSI 1M dalam EC:DEC (1:1) dan BMIMTFSI (95\%:5\%, v/v)

\section{Pengukuran Konduktivitas Ionik Elektrolit}

Pengukuran konduktivitas elektrolit dilakukan dengan menggunakan teknik Impedance Electrochemical Spectroscopy (EIS). Pengukuran dilakukan pada susunan sel yang menggunakan stainless steel sebagai kedua elektrodanya (stainless steel | elektrolit | stainless steel). Hioki 3532-50 LCR Hi-Tester digunakan untuk pengukuran konduktivitas ionik dengan range frekuensi $42 \mathrm{~Hz}-1 \mathrm{MHz}$. Pada penelitian ini, terdapat dua metode yang digunakan untuk menentukan konduktivitas ionik elektrolit baterai ion litium. Metode pertama menggunakan nilai reistansi bulk $\left(\mathrm{R}_{\mathrm{b}}\right)$ yang ditentukan dari plot Nyquist (plot impedansi real Z' vs impedansi imajiner Z" pada rentang frekuensi yang diukur). Dengan dimensi sel yang diketahui, maka konduktivitas elektrolit dapat diperoleh dengan menggunakan persamaan (1) ${ }^{[21]}$.

$$
\sigma=\frac{t}{A} \frac{1}{R_{b}}
$$

di mana $t$ adalah ketebalan sampel $(\mathrm{cm}), A$ merupakan luas area efektif elektroda yang saling kontak $\left(\mathrm{cm}^{2}\right)$ dan $R_{b}$ merupakan resistansi bulk $(\Omega)$. Pada penelitian sampel yang digunakan memiliki ketebalan sebesar $8,5 \mathrm{~mm}$ dan luas area sebesar 2,01 $\mathrm{m}^{2}$.

Metode kedua menggunakan pendekatan eksperimen dari plot kebergantungan konduktivitas AC terhadap frekuensi yang diperoleh dari Hukum Jonscher's Power untuk konduktivitas ionik, yaitu ${ }^{[22]}$ :

$$
\sigma_{\omega}=\sigma_{0}+A \omega^{s}
$$

di mana $\sigma_{\omega}, \sigma_{0}$, A dan s merupakan konduktivitas AC bulk, konduktivitas DC, konstanta konduktivitas AC dan power konduktivitas AC. Konduktivitas DC $\left(\sigma_{0}\right)$ merupakan konduktivitas ionik yang diperoleh dari bagian datar yang teramati pada konduktivitas bulk AC. Konduktivitas bulk AC $\left(\sigma_{\omega}\right)$ pada setiap frekuensi $\omega$ dihitung dari hasil pengukuran pada plot Bode dengan menggunakaan persamaan (3).

$$
\sigma_{\omega}=\frac{t}{A}\left(\frac{z^{r}}{z^{r 2}+z^{n 2}}\right)
$$




\section{HASIL DAN PEMBAHASAN}

Konduktivitas ionik merupakan parameter penting dari karakteristik elektrolit. Konduktivitas ionik elektrolit akan mempengaruhi performa baterai ion litium. Konduktivitas ionik memainkan peran penting selama proses interkalasi dan deinterkalasi ion pembawa muatan pada material elektroda. Besar kecilnya konduktivitas ionik suatu elektrolit dipengaruhi oleh kemampuan mobilitas ion dari katoda ke anoda atau sebaliknya. Konduktivitas ionik yang mengukur kemampuan konduksi ion menggambarkan pengaruh dua aspek yakni disosiasi ion dan migrasi ion.

Nilai konduktivitas ionik berbanding terbalik dengan nilai resistansi bulk sistem elektrolit. Pada penelitian ini, konduktivitas ionik elektrolit diukur dengan teknik Electrochemical Impedance Spectroscopy (EIS). Hasil spektrum impedansi dengan karakteristik plot Nyquist pada pengukuran konduktivitas elektrolit ditunjukkan pada Gambar 1.

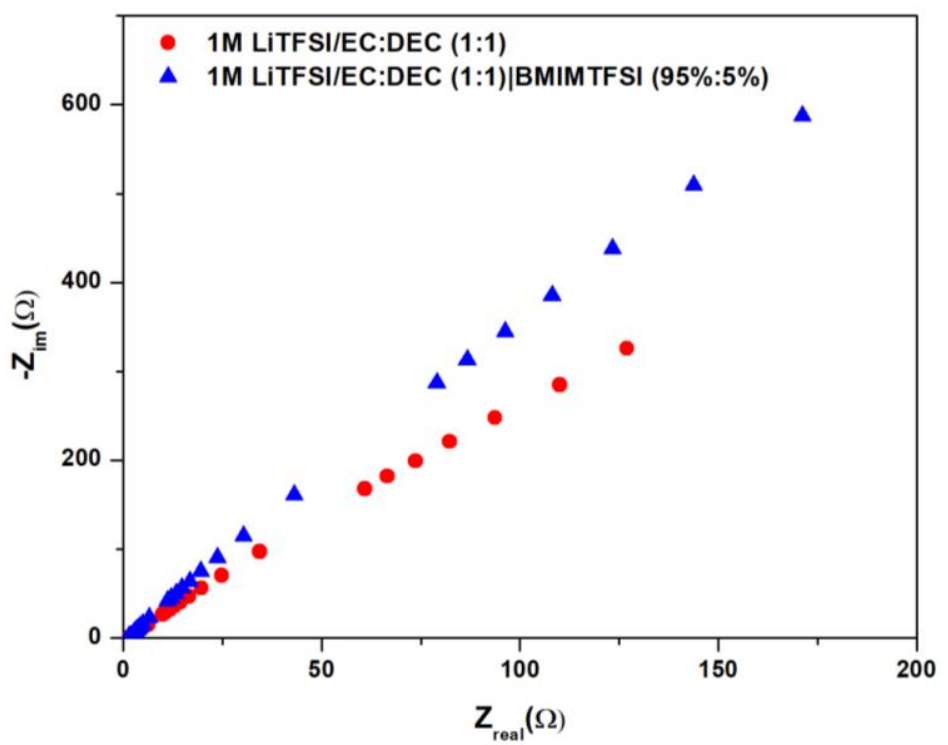

Gambar 1. Plot Nyquist sel stainless steel/stainless steel pada elektrolit yang berbeda

Hasil spektrum impedansi pada Gambar 1 digunakan untuk menghitung konduktivitas ionik elektrolit. Konduktivitas ionik elektrolit dari 1M LiTFSI dalam EC:DEC dan 1M LiTFSI dalam EC:DEC/BMIMTFSI (95\%:5\%, v/v) diukur pada suhu ruang. Sedangkan konduktivitas ionik elektrolit bergantung frekuensi ditunjukkan pada Gambar 2.

Seperti ditunjukkan pada Gambar 2, konduktivitas ionik elektrolit terdiri dari dua daerah dalam rentang frekuensi yang teramati. Daerah pada frekuensi rendah terjadi akibat efek polarisasi elektroda dan daerah datar yang menunjukkan ketidakbergantungannya pada frekuensi menggambarkan konduktivitas DC elektrolit ${ }^{[23]}$. 


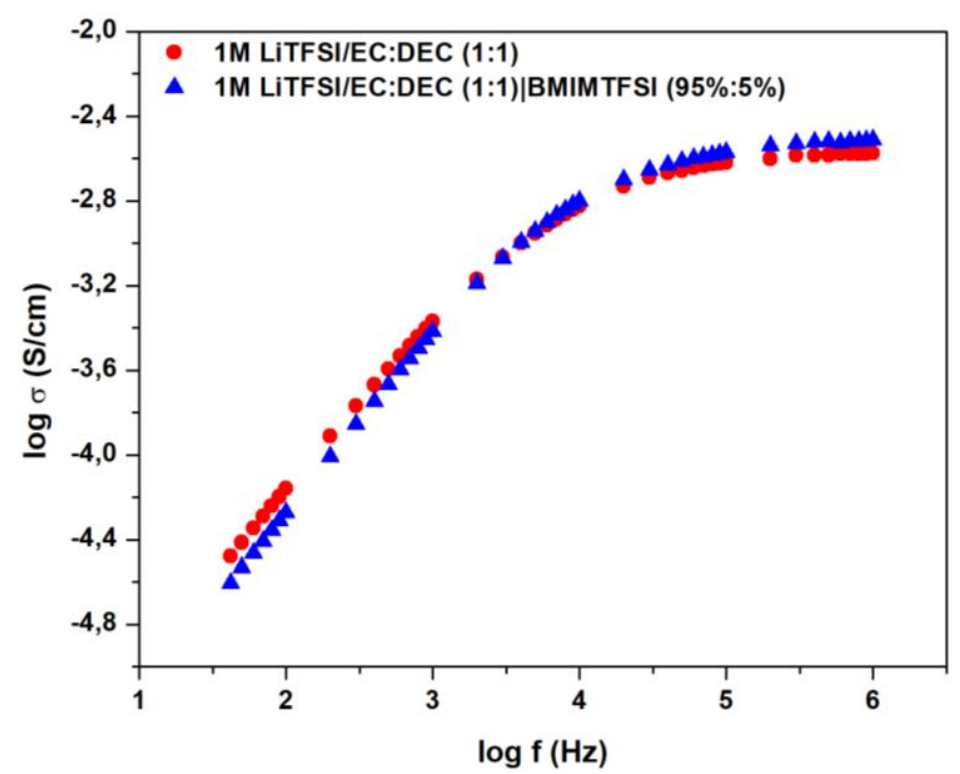

Gambar 2. Spektrum log konduktivitas ionik vs log frekuensi pada elektrolit yang berbeda

Besarnya konduktivitas ionik elektrolit diperoleh dengan cara menentukan estimasi resistansi bulk berdasarkan plot Nyquist dengan melakukan fitting data EIS dari plot Nyquist yang terdapat pada Gambar 1 menggunakan software EIS Spectrum Analyser. Proses fitting tersebut dilakukan dengan menggunakan model rangkaian setara seperti yang ditunjukkan pada Gambar 3 dan parameter hasil fitting ditunjukkan pada Tabel 2.'

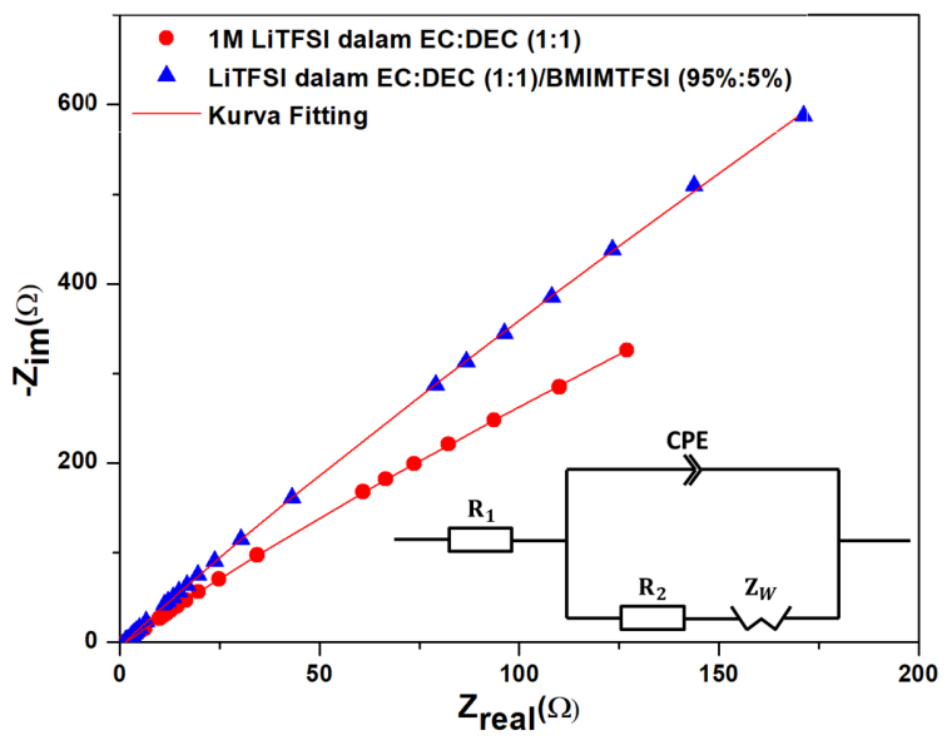

Gambar 3. Kurva EIS sel stainless steel/stainless steel pada berbagai elektrolit dan rangkaian setara EIS

Model rangkaian setara dari data EIS digunakan untuk mengetahui sifat fisis dari sistem elektrokimia dengan pemodelan data impedansi dalam rangkaian listrik setara. Karena kita berhadapan dengan sistem real yang tidak selalu berperilaku ideal, maka kita dapat menggunakan elemen khusus seperti constant phase element (CPE) dan impedansi Warburg $\left(Z_{W}\right)$. Rangkaian setara tersebut memberikan kemungkinan terbaik yang sesuai antara model impedansi dengan sistem impedansi yang terukur. 
Tabel 2. Nilai parameter data fitting setiap komponen pada model rangkaian setara sel stainless steel/stainless steel

\begin{tabular}{lcc}
\hline Parameter & 1M LiTFSI dalam EC:DEC $(1: 1)$ & $\begin{array}{c}\text { LiTFSI dalam } \\
\text { EC:DEC(1:1)/BMIMTFSI } \\
(95 \%: 5 \%, \mathrm{v} / \mathrm{v})\end{array}$ \\
\hline $\mathrm{R}_{1}(\Omega)$ & 1,5575 & 1,351 \\
$\mathrm{R}_{2}(\Omega)$ & 1725,1 & 790,13 \\
$\mathrm{Z}_{W}\left(\Omega \mathrm{s}^{-0.5}\right)$ & 22495 & 60729 \\
$\mathrm{CPE}(\mu \mathrm{F})$ & 28,21 & 12,208 \\
$\mathrm{n}$ & 0,81572 & 0,86294 \\
\hline
\end{tabular}

Dari interpretasi data impedansi tersebut telah didapatkan nilai resistansi bulk yang ditunjukkan oleh nilai $\mathbf{R}_{1}$. Nilai $\mathbf{R}_{1}$ menunjukkan karakteristik bulk sistem elektrolit yang bersifat ohmik dan selalu muncul pada frekuensi tinggi. Dengan menggunakan persamaan (1), maka konduktivitas ionik 1M LiTFSI dalam EC:DEC (1:1) dan 1M LiTFSI dalam EC:DEC(1:1)/BMIMTFSI (95\%:5\%, v/v) dapat diketahui, masing-masing pada suhu ruang yaitu $2,7 \mathrm{mS} / \mathrm{cm}$ dan $3,1 \mathrm{mS} / \mathrm{cm}$. Elektrolit LiTFSI dengan tambahan cairan ionik BMIMTFSI memiliki konduktivitas ionik lebih tinggi dibandingkan dengan elektrolit LiTFSI tanpa cairan ionik. Besar konduktivitas ionik elektrolit dalam penelitian ini masih sedikit lebih rendah dibandingkan dengan hasil yang diperoleh oleh Murmann, dkk yang menggunakan garam litium LiDMSI dan LiHPSI dengan menggunakan pelarut EC dan DEC [24]. Namun jika dibandingkan dengan hasil penelitian Garcia, dkk yang menggunakan 1M LiTFSI dalam EMI-TFSI, konduktivitas ionik elektrolit yang diperoleh pada penelitian memiliki nilai yang lebih tinggi ${ }^{[25]}$. Dengan memperhatikan kriteria elektrolit yang dapat digunakan untuk aplikasi baterai ion litium adalah memiliki konduktivitas ionik di atas $10^{-1} \mathrm{mS} / \mathrm{cm}{ }^{[3]}$, maka konduktivitas ionik elektrolit dalam penelitian ini memenuhi kriteria yang diharapkan untuk aplikasi baterai ion litium.

\section{KESIMPULAN}

Penambahan cairan ionik BMIMTFSI dapat meningkatkan konduktivitas ionik elektrolit LiTFSI. Besarnya konduktivitas ionik elektrolit yang diperoleh pada penelitian ini masih cukup rendah, namun memenuhi kriteria yang diharapkan untuk aplikasi baterai ion litium.

\section{DAFTAR PUSTAKA}

1 Zhang, B., Zhou, Y., Li, X., Ren, X., Nian, H., Shen, Y., \& Yun, Q. 2013. Ionmolecule Interaction in Solutions of Lithium Tetrafluoroborate in Propylene Carbonate: an FTIR Vibrational Spectroscopic Study. Int. J. Electrochem. Sci, 8, $12735-12740$

2 Yang, H., Zhuang, G. V., \& Ross, P. N. 2006. Thermal stability of LiPF 6 salt and Liion battery electrolytes containing LiPF. Journal of Power Sources, 161(1), 573-579

3 Goodenough, J. B. \& Kim, Y. 2010. Challenges for Rechargeable Li Batteries. Chem. Mater, 22, 587-603

4 Kawamura, T., Okada, S., \& ichi Yamaki, J. 2006. Decomposition reaction of LiPF6based electrolytes for lithium ion cells. J. Power Sources, 156(2), 547-554

5 Chen, Z., Lu, W. Q., Liu, J., \& Amine, K. 2006. LiPF 6 /LiBOB blend salt electrolyte for high-power lithium-ion batteries. Electrochim. Acta, 51(16), 3322-3326

6 Lux, S. F., Lucas, I. T., Pollak, E., Passerini, S., Winter, M., \& Kostecki, R. 2012. The mechanism of $\mathrm{HF}$ formation in $\mathrm{LiPF}_{6}$ based organic carbonate electrolytes. 
Electrochem. commun, 14(1), 47-50

7 Dougassa, Y. R., Tessier, C., El Ouatani, L., Anouti, M., \& Jacquemin, J. 2013. Low pressure carbon dioxide solubility in lithium-ion batteries based electrolytes as a function of temperature. Measurement and prediction. J. Chem. Thermodyn, 61, 32-44

8 Zhang, L., Chai, L., Zhang, L., Shen, M., Zhang, X., Battaglia, V. S., Stephenson, T., \& Zheng, H. 2014. Synergistic effect between lithium bis (fluorosulfonyl) imide (LiFSI) and lithium bis-oxalato borate (LiBOB) salts in $\mathrm{LiPF}_{6}$-based electrolyte for high-performance Li-ion batteries. Electrochimica Acta, 127, 39-44

9 Zhang, S. S., Xu, K., \& Jow, T. R. 2006. Enhanced performance of Li-ion cell with $\mathrm{LiBF}_{4}-\mathrm{PC}$ based electrolyte by addition of small amount of LiBOB. J. Power Sources, 156(2), 629-633

10 Shieh, D. T., Hsieh, P. H., \& Yang, M. H. 2007. Effect of mixed LiBOB and LiPF6 salts on electrochemical and thermal properties in LiMn2O4 batteries. J. Power Sources, 174(2), 663-667

11 Bolloli, M., Alloin, F., Kalhoff, J., Bresser, D., Passerini, S., Judeinstein, P., Leprêtre, J. C., \& Sanchez, J. Y. 2015. Effect of carbonates fluorination on the properties of LiTFSI-based electrolytes for Li-ion batteries. Electrochimica Acta, 161, 159-170

12 Yang, B., Li, C., Zhou, J., Liu, J., \& Zhang, Q. 2014. Pyrrolidinium-based ionic liquid electrolyte with organic additive and LiTFSI for high-safety lithium-ion batteries. Electrochim. Acta, 148, 39-45

13 Zhang, X., Kostecki, R., Richardson, T. J., Pugh, J. K., \& Ross, P. N. 2002. Electrochemical and Infrared Studies of the Reduction of Organic Carbonates. $J$. Electrochem. Soc, 148(12), A1341

14 Gnanaraj, J. S., Thompson, R. W., DiCarlo, J. F., \& Abraham, K. M. 2007. The Role of Carbonate Solvents on Lithium Intercalation into Graphite. J. Electrochem. Soc, 154(3), A185

$15 \mathrm{Xu}$, K. 2004. Nonaqueous Liquid Electrolytes for Lithium-Based Rechargeable Batteries. Chem. Rev, 104(10), 4303-4418

16 Vogl, T., Menne, S., \& Balducci, A. 2014. Mixtures of protic ionic liquids and propylene carbonate as advanced electrolytes for lithium-ion batteries. Phys. Chem. Chem. Phys, 16(45), 25014-25023

17 Yim, T., Kwon, M. S., Mun, J., \& Lee, K. T. 2015. Room temperature ionic liquidbased electrolytes as an alternative to carbonate-based electrolytes. Isr. J. Chem, 55(5), 586-598

18 Wilken, S., Xiong, S., Scheers, J., Jacobsson, P., \& Johansson, P. 2015. Ionic liquids in lithium battery electrolytes: Composition versus safety and physical properties. $J$. Power Sources, 275, 935-942

19 Galiński, M., Lewandowski, A., \& Stepniak, I. 2006. Ionic liquids as electrolytes. Electrochim. Acta, 51(26), 5567-5580

20 Srivastava, A. K., \& Samant, R. A. 1994. Ionic Conductivity in Binary Solvent Mixtures. 1. Propylene Carbonate $(20$ mass $\%)+$ Ethylene Carbonate at $25^{\circ} \mathrm{C} . J$. Chem. Eng. Data, 39, 358-360

21 Osman, Z., Mohd Ghazali, M. I., Othman, L., \& Md Isa, K. B. 2012. AC ionic

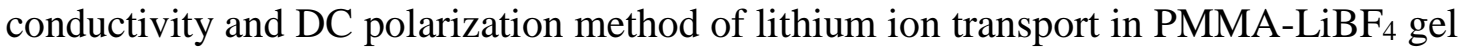
polymer electrolytes. Results Phys, 2, 1-4

22 Nasri, S., Ben Hafsia, A. L., Tabellout, M., \& Megdiche, M. 2016. Complex impedance, dielectric properties and electrical conduction mechanism of $\mathrm{La}_{0.5} \mathrm{Ba}_{0.5} \mathrm{FeO}_{3}-\delta$ perovskite oxides, $R S C A d v, 6(80)$, 76659-76665 
23 Vijaya, N., Selvasekarapandian, S., Malathi, J., Iwai, Y., Nithya, H., and Kawamura J. 2012. CONDUCTIVITY AND 1H NMR STUDIES ON PVP: $\mathrm{NH}_{4} \mathrm{Br}$ POLYMER ELECTROLYTE, Proceeding of the 13th Asian Conference on Solid State Ionics, 342-333.

24 Murmann, P., Niehoff, P., Schmitz, R., Nowak, S., Gores, H., Ignatiev, N., Sartori, P., Winter, M., \& Schmitz, R. 2013. Investigations on the electrochemical performance and thermal stability of two new lithium electrolyte salts in comparison to LiPF6. Electrochimica Acta, 114, 658-666

25 Garcia, B., Lavalle, S., Gerald, P., Michot, C., \& Armand, M. 2004. Room temperature molten salts as lithium battery electrolyte. Electrochim. Acta, 49, 45834588 